\title{
Study on the Spread of Procambarus clarkii at Gharb (Morocco) and Its Impact on Rice Growing
}

\author{
Saguem Sara $^{1}$ and Majida El Alami El Moutaouakil ${ }^{1,2}$ \\ 1. Research Team Ecology, Systematics, Conservation of Biodiversity, Department of Biology, Faculty of Science, Avenue Sebta, \\ 93002 Tetouan, Morocco \\ 2. Department of Biology, Faculty of Science, Abdelmalek Essaadi University, Avenue Sebta, 93002 Tetouan, Morocco
}

\begin{abstract}
The red swamp crayfish (Procambarus clarkii) is a species from the northeast of Mexico and the central south of the United States (Louisiana), actually is the dominant macroinvertebrate in several countries. It was introduced to several countries, generally for gastronomic reasons or to repopulate destroyed areas by a disease. While the first introduction of this species into the world is well-documented, little is known about its pathways of invasion and the reason for its rapid spread in several countries. $P$. clarkii is an aggressive crustacean that multiplies very fast and adapts to features of the invaded location. Adults of the species can disperse up to $1.6 \mathrm{~km}$ on land. Also, they dig deep holes which allows them to establish easily in wetlands and adjacent waterbodies that are hydrologically disconnected. This study takes place in the Gharb area (northwestern of Morocco) where several carcasses of P. clarkii have been found in different places. In the present study, it is a question of understanding how this species was introduced in this area, to establish a map of propagation of the species, and to evaluate the damage that it would have caused in the rice growing of Gharb. In Morocco, it was first sighted in the Gharb area in 2008 in the commune of Sidi Allal Tazi. Following this discovery, possible ways of the species introduction and the dispersal modes were explored that $P$. clarkii could use to invade the Gharb area. The results of this study can be used by natural resource managers, rice farmers, fishermen and the local population, to help them to locate the spread of $P$. clarkii, to identify vectors that move $P$. clarkii across political boundaries and illustrate the importance of limiting and prohibiting the movement of this invasive species across boundaries or into new ecosystems.
\end{abstract}

Key words: Procambarus clarkii, rice growing, map of propagation, Gharb, Morocco.

\section{Introduction}

Man throughout history has experienced of movements and migrations, since then, he has brought with him, voluntarily or not, many animal and plant species outside their natural living areas. In fact, the modernization of the means of transport, the increased travel, tourism development and the increase of international exchanges trade have favored the importation, voluntary or fortuitous, of new species within the new territories around the planet.

The human-mediated introduction of species outside their native ranges has recently emerged as one of the "big five" issues of concern in conservation [1]. Many of these introductions are indeed beneficial

Corresponding author: Saguem Sara, Ph.D. student, research field: biology. to humans [2] or cause minimal environmental impacts [3, 4]. Only a small, but significant proportion of nonindigenous species become invasive, meaning that they become numerically and ecologically prominent, spread from the point of introduction, and are often capable of dominating indigenous populations and communities [5].

The introduction of Procambarus clarkii from the Southern United States and Northern Mexico [6], around the world through the growth of international trade is an example.

The red swamp crayfish (P. clarkia) [7], belongs to the Cambaridae family is distinguished by their red, sometimes bluish or purplish coloring, and generally live between three and five years. On average, they weigh $25 \mathrm{~g}$ (some can exceed $50 \mathrm{~g}$ ) and measure $6 \mathrm{~cm}$ and $12 \mathrm{~cm}$ without its claws. Its claws are granular 
and covered with red spots $[8,9]$.

$P$. clarkii is omnivorous and its diet is classified as selective and successive: it attacks, preferably, aquatic grass until exhaustion. Then mollusks, frog tadpoles, eggs and young fish follow each other [10].

With regard to native species, Louisiana crayfish adopt an aggressive behavior. $P$. clarkii compete with other species, attacking them to the point of extinction [11]. It is a very harmful species and introducing as an ecological error [12]. Indeed, this invasive species has various impacts and can imbalance ecosystems that it has been introduced.

In Africa, Uganda and Kenya are the first countries to introduce Louisiana crayfish between 1963 and 1970. It was intended to be used as a biological control tool against aquatic molluscs that are vectors of bilharzia but also as a source of protein to undernourished populations [12].

In Morocco, this study is one of the first studies in the country after a study that was done at the Merja zarga wetland and Nador canal in 2015 [13].

This study in particular is the first in the whole of Gharb (northwest of Morocco). Since the introduction of the red swamp crayfish in the study area, several changes have been observed, like the excavated tunnels that cause loss of irrigation water, loss of arable land and fall in rice yield.

The quality of the land fertility, the humid temperate climate and the abundance of water resources make this area one of the most important agricultural regions in Morocco [14].

The main objectives of this study were to confirm the presence of $P$. clarkii in the Gharb area, investigate the causes of introduction of this species into the study area, delimit the spread of this species geographically, and identify the impacts of this species on the Gharb rice growing.

\section{Materials and Methods}

\subsection{Study Area}

The Gharb area is located into central of Morocco, in the Rabat-Salé-Kenitra region that spreads over an area of $17,570 \mathrm{~km}^{2}, 2.5 \%$ of the area of the kingdom of Morocco (Fig. 1). It is bounded on the north by the Tangier-Tetouan region, on the east by the Fez-Meknes region, on the southwest by the Casa-Settat region, on the southeast by the Beni Mellal-Khénifra region, and on the west by the Atlantic Ocean.

The Gharb region is located in the northwestern part of Morocco. Crossed from east to west by the Sebou River, the Gharb extends about 50 miles $(80 \mathrm{~km})$ along the Atlantic coast and reaches some 70 miles (110 km) inland (Fig. 1).

The area is crisscrossed by tributaries of the Sebou River for a length of approximately $225 \mathrm{~km}$ before flowing into the Atlantic Ocean at Mehdia. Along its route, the Sebou intercepts several tributaries, the most important of which are the wadis Inaouène, Lebène and especially Ouergha on the right bank and wadis R'dom and Beht on the left bank.

The Gharb area has considerable water resources, estimated at 6.75 billion cubic metres, whose part reserved for irrigation is 3.5 billion cubic metres.

The area enjoys a Mediterranean climate with an oceanic influence; it belongs to the subhumid bioclimatic stage at temperate winter with a semi-arid tendency in internal zones. In addition, the area has a wide range of soil type. The Gharb area is favorable to rice growing due to many ecological factors like climate, soil and water quality (Fig. 2).

In the Gharb area, rice growing amounts to 12,000 ha. There are seven rice-growing areas in the Gharb plain, which includes 40 cooperatives (Fig. 2):

- Sector S1: composed of a group of Melk and collective lands belonging to the rural commune Sidi Kamel;

- Sector S3: grouping four cooperatives, belonging to the rural commune Sidi Kamel;

- Sector S5: grouping seven cooperatives;

- Sector S7: composed of four cooperatives, including three in the rural commune of HOUAFAT and one in the rural commune Sidi Kamel; 


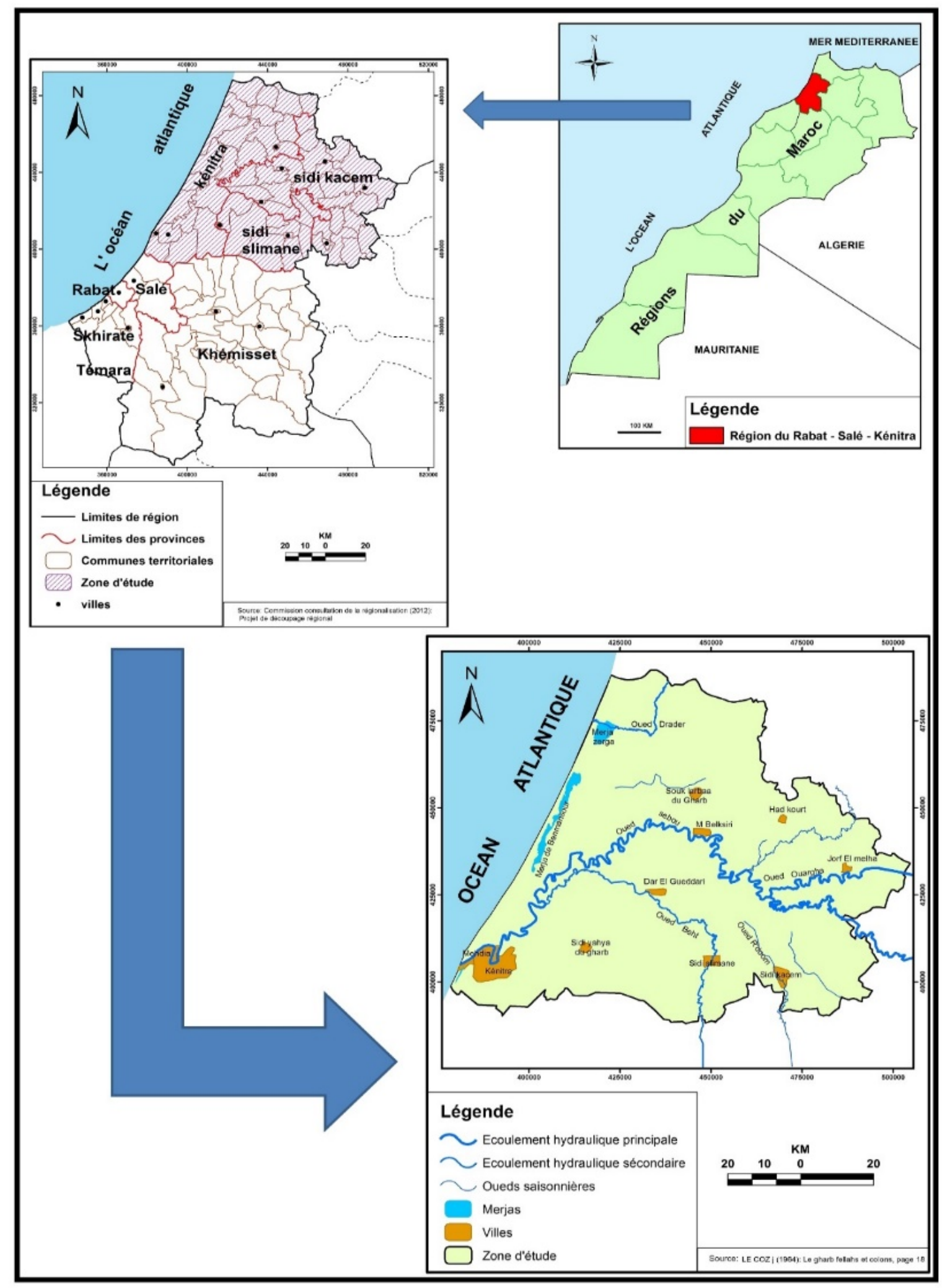

Fig. 1 Location of the Gharb area (Regional Office for Agricultural Development of Gharb, Morocco, 2016). 


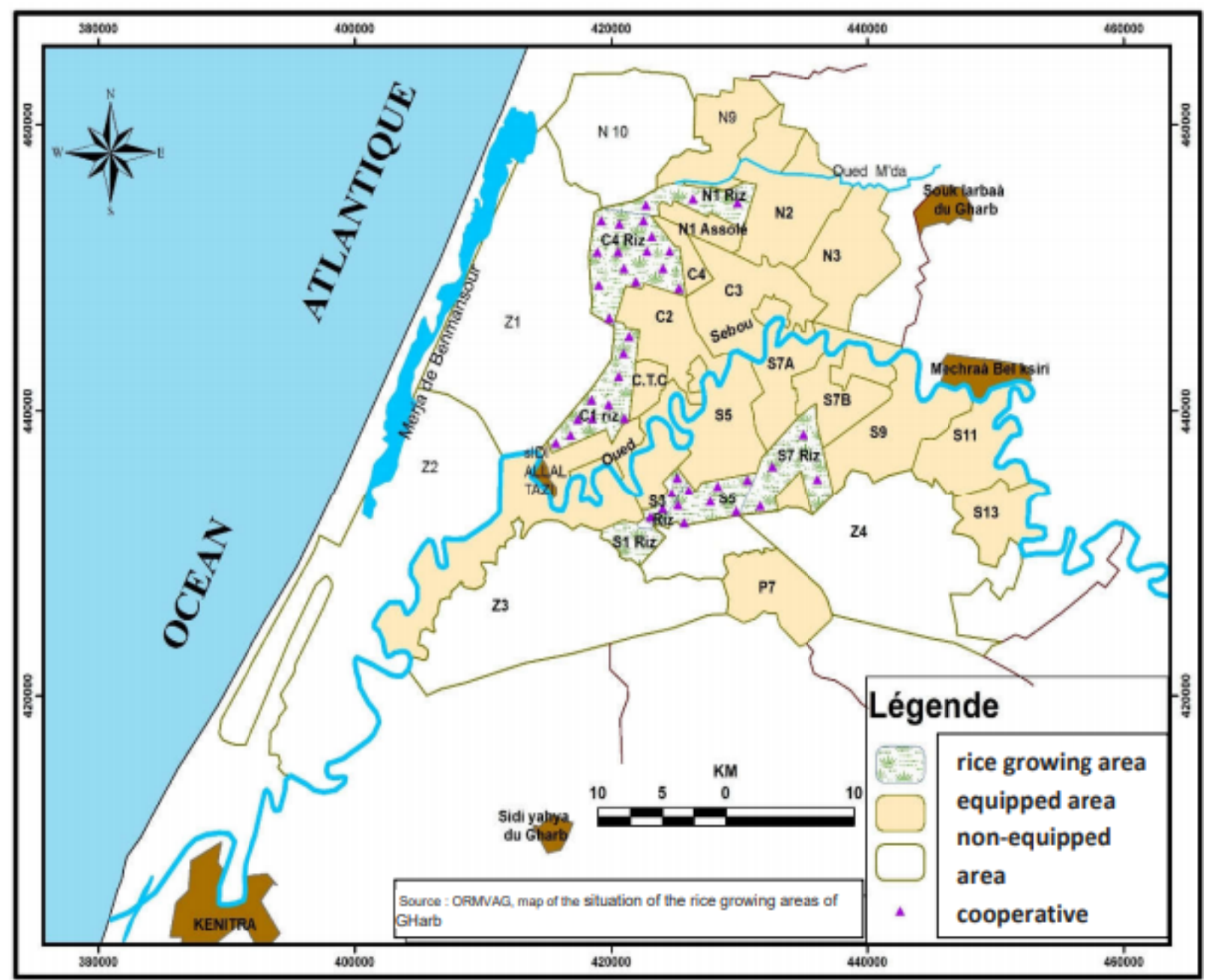

Fig. 2 Spatial situation of rice-growing areas of the Gharb and cooperatives is the rice sector (modified card, Regional Office for Agricultural Development of Gharb, Morocco).

- Sector C1: comprising ten cooperatives, nine of which are located in the rural district of Sidi Allal Tazi and one in Ben Mansour;

- Sector C4: grouping 14 cooperatives located in the rural commune Souk Tlet of Gharb;

- Sector N1: composed of three cooperatives belonging to the rural commune Sidi Mohamed Lahmar.

\subsection{Sampling Methods and Materials}

To achieve the objectives, several technical and scientific processes were used to obtain information, measure dimensions and calculate results.

Data on the propagation of $P$. clarkii, and the dates of its first sighting in the Gharb area were collected by the distribution of anonymous surveys, approved by the Department of Water and Forests and the Fight against Desertification North West Kenitra Morocco, in collaboration with the University Abdelmaled Essaadi Faculty of Science Tetouan Morocco.

To evaluate the risk of dispersal of $P$. clarkii, survey sites were initially selected on the basis of expert advice from the Department of Water and Forests and the Fight against Desertification North West Kenitra Morocco.

Five hundred and ninety (590) people were interviewed in totality and 478 rice farmers were interviewed between April and October 2015 to 
identify impacts of $P$. clarkii on rice cultivation.

2.2.1 Methods of Catching Crayfish in Paddy Fields and Dike

In the rice fields, the red swamp crayfish was caught using the hand-fishing technique.

In the dikes, two methods were used depending on the dimensions of the dyke:

\begin{tabular}{|c|c|}
\hline $\begin{array}{l}\text { (1) Dikes and river of } \\
\text { small width (less than } 3 \mathrm{~m} \text { ) } \\
\text { and shallow depth (less } \\
\text { than } 0.30 \mathrm{~m} \text { ) }\end{array}$ & $\begin{array}{l}\text { (2) Dikes and river } \\
\text { (greater than } 0.30 \mathrm{~m} \text { ) }\end{array}$ \\
\hline $\begin{array}{l}\text { Hand-fishing technique to } \\
\text { catch the red swamp } \\
\text { crayfish }\end{array}$ & $\begin{array}{l}\text { Landing net technique to } \\
\text { catch the red swamp } \\
\text { crayfish }\end{array}$ \\
\hline
\end{tabular}

2.2.2 Abundance of Louisiana Crayfish in Paddy Fields

In the middle of randomly selected rice fields, the field team measured several plots in the shape of $1 \mathrm{~m}^{2}$ (Fig. 3), then counted the number of holes dug by crayfish in each square, then counted the number of crayfish present in each hole. Also the diameter measurement and the depth of the holes present in the plot are used to calculate the water loss (Fig. 4).

A questionnaire has been used to confirm the presence of $P$. clarkii in the study area. A cylindrical net with a length of $2 \mathrm{~m}$ and stretched mesh size of 13 $\mathrm{mm}$ is used to capture the species in dikes and irrigation channels.

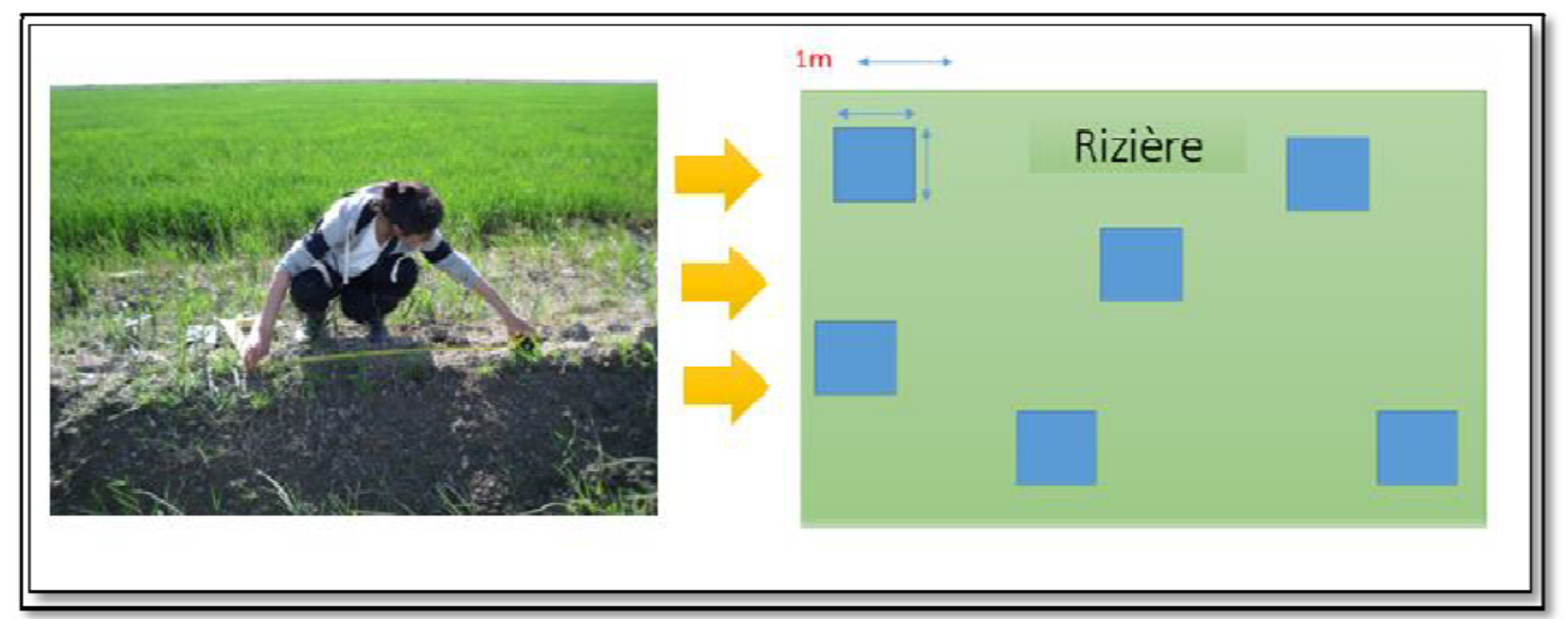

Fig. 3 Plot area measurements for calculating crayfish abundance, rice growing, Gharb area, Morocco, 2016.

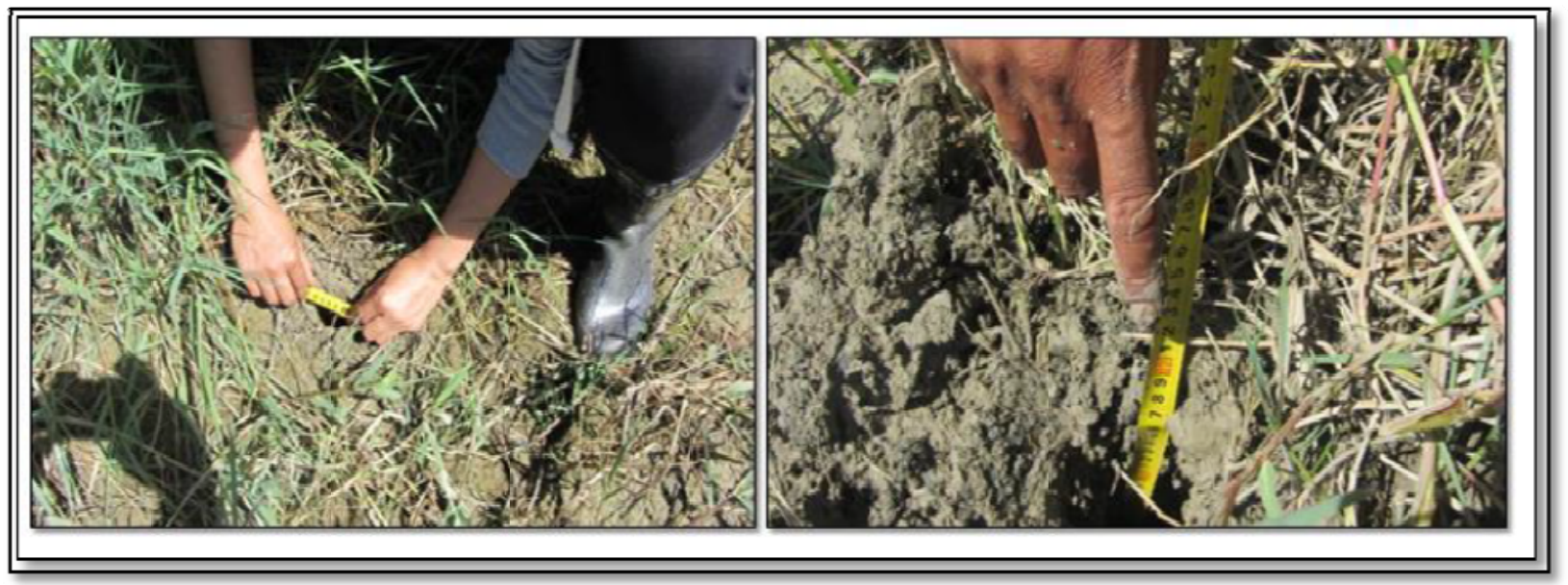

Fig. 4 Measuring dimensions of a crayfish hole in rice growing, Gharb area, Morocco, 2016. 
A camera is used to take the images, a tape to measure the depth of the holes dug by the crayfish, and a macroinvertebrate determination key to identify the species.

\section{Results and Discussion}

\subsection{Propagation of Red Swamp Crayfish in Gharb} Area

According to the results of the survey of rice farmers and the local population, the species was observed in the first time in the rural district of Sidi Allal Tazi, around 2008 (rice farmers survey, saguem 2016). Its presence in that area could only be made by a clandestine introduction and by people to test the degree of its acclimatization to the ecological conditions of the area (Fig. 5).

According to the testimonies of the commune farmers, and the field trips since April 2015 to collect the red swamp crayfish to confirm its presence and the date of its first observation in the study area, the species was seen for the first time in the fields of culture, irrigation canals and in the Oued Sebou.

In 2010/2011, in Kenitra, the species was found in the Ramsar Merja Fouwarate site, a wetland located at the southwestern end of the Gharb coastal plain. The population of Fouwarate and some researchers of the Faculty of Sciences of the University Ibn Tofail of Kenitra, Morocco, confirmed that the presence of this species dates back to 2010. And it was during the flood of Oued Sebou, in 2010 that the spread has be done.

According to the fishermen of the rural commune of Moulay Bousselham, the presence of the crayfish in the Merja Zarga and Canal Nador which takes its source directly in the Oued Sebou dates back also to 2010.

The population of the rural commune of Mnasra and the commune Ouled Slama use the water of Oued Sebou directly for irrigation. According to their testimonies, the presence of $P$. clarkii was directly related to the 2010 flood because it was just after this period that the species was first observed in this area.

Mograne rural commune reportedly observed the species in 2010/2011 in the Beht River which is the source of irrigation water for these municipalities.

The rural commune of Benmansour directly exploits the water that comes from Oued Sebou in the practice of irrigation. The population claims that it was in 2011, during the flood, that the crayfish was introduced into the area.

In the rural communes of Sidi Al Kamel and Souk Telet El Gharb, the first observations date back to 2012/2013. Irrigation of crops in this area is done successively through Oued Rdom and Oued Sebou.

The population of Sidi Mohamed Lahmar rural commune observed the crayfish in 2014/2015 in their zones.

The douars farmers of the rural commune of Mechra Bel Ksiri, exploit the Sebou wadi water for crop irrigation, observed the red swamp crayfish for the first time in 2014.

Farmers in the rural commune of Dar Gueddari are using water from Oued Beht for crop irrigation and have confirmed that the $P$. clarkii would have appeared in 2014.

Finally, in the rural commune of Al Houafate, it is in 2015 that the crayfish would have been observed.

After the introduction of the crayfish into the irrigation channels of Sidi Allal Tazi, the spread seems to be in two different directions. The first one is along the Sebou River from upstream to downstream, so there was contamination of the Southern Beht River and the Rdom River successively in 2010 and 2013. The evolution along this direction is fast as evidenced by the contamination of the Fouwarat wetland in Kenitra that occurred just after a year. In the other direction, the crayfish takes the path of the irrigation canals to propagate in the rice fields. This second form of propagation is slower than the first because the crayfish has to wait for the filling of the irrigation dikes to continue its evolution. 


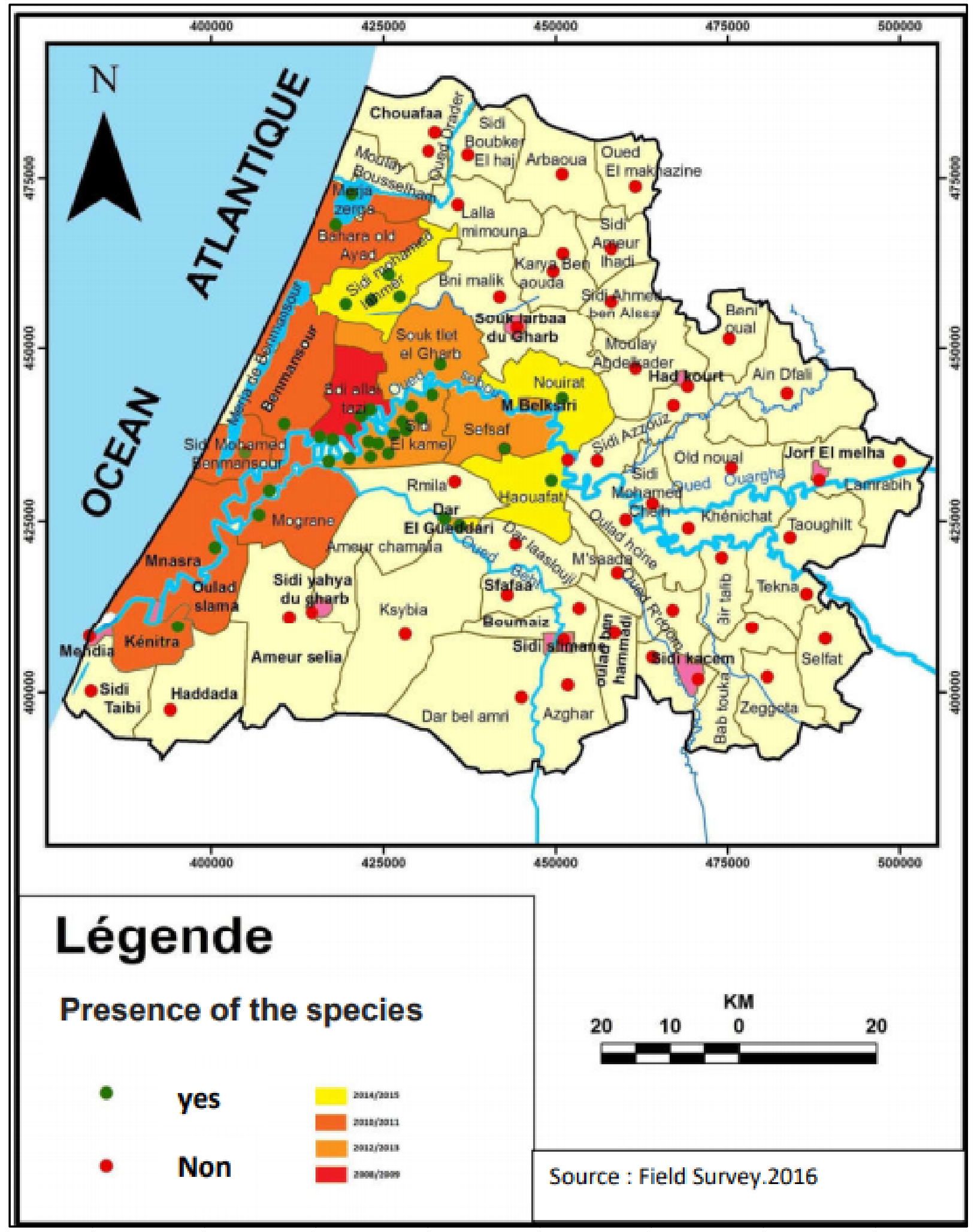

Fig. 5 Spread of Procambarus clarkii in Gharb area, Morocco, 2016 (modified card, Regional Office for Agricultural Development of Gharb, Morocco, 2016). 
The species has not yet arrived to colonize the entire Gharb area. To the North, this crustacean did not reach the Arbaoua, Oued El Makhazine, Kariat Ben Aouda, Beni Malek and Souk Larbaa communes of Gharb. To the East, the communes of Had Kourt and Jorf El Melha are not yet affected by this species since Oued Ouargha is not contaminated. In the South, the Sidi Yahya commune of Gharb does not yet know the presence of this species.

\subsection{Damage Caused by Red Swamp Crayfish on Rice Growing}

The rice fields is an agro-ecosystem that remain flooded almost permanently during the cultivation period (end of April to mid-September), and is dry the rest of the year.

The red swamp crayfish are digging holes in rice fields and dikes. These holes serve as habitat and also a way to escape in case of attack (Figs. 6a and 6b).

These galleries serve as habitat but also a way to escape in case of attack. The presence of these drifts induces a loss of water which increases in parallel with the number of holes dug in the sector (rice farmers in the Gharb zone, Morocco, 2016) (Fig. 6).

These holes have important dimensions. In the areas where it made the samples, there are up to 2 holes $/ \mathrm{m}^{2}$ maximum. These holes can reach maximum average depths of $2.5 \mathrm{~m}$ and maximum diameters of $4.5 \mathrm{~cm}$ (Fig.7).

The number of holes per square meter and the number of crayfish in a hole will allow the calculation of the number of crayfish per square meter (Fig. 8). Then, by unit conversion, the number of crayfish per hectare that is absolute abundance will be got.

The irrigation of rice fields in Gharb area is characterized by a number of filling and emptying of water. The number of emptying and filling of rice farms during the whole rice cycle varies according to the condition of irrigation channels of rice growers and to the position of the closed on the tertiary sector.

Once the first paddy field is well irrigated, the rice farmer blocks the entry of water into the bunds (Fig. 9a), to pass it into the other fields (water towers) (Fig. 9b). The process is repeated until the bunds of the last paddy field.

In addition, the burrows that the red swamp crayfish digs into the dikes cause water loss, the properties of rice fields that are near the water source are forced to fill several times their bunds. This penalizes other rice farmers working on land downstream of the water source [14].

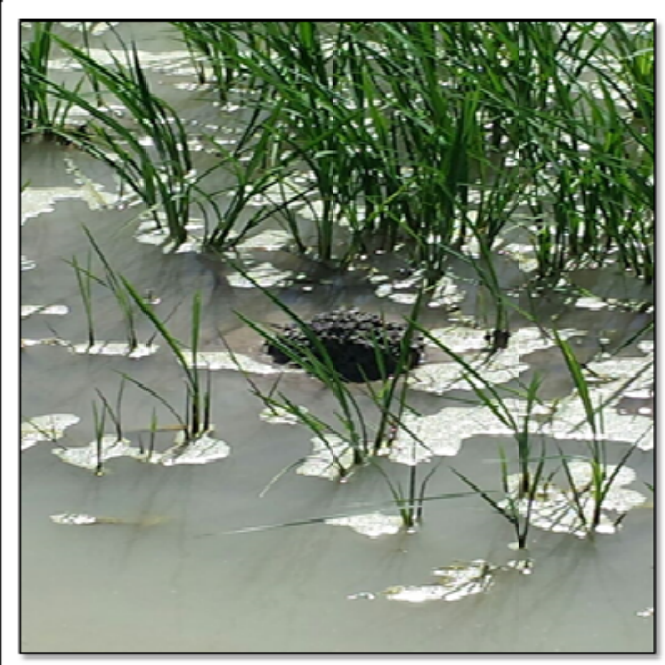

(a)

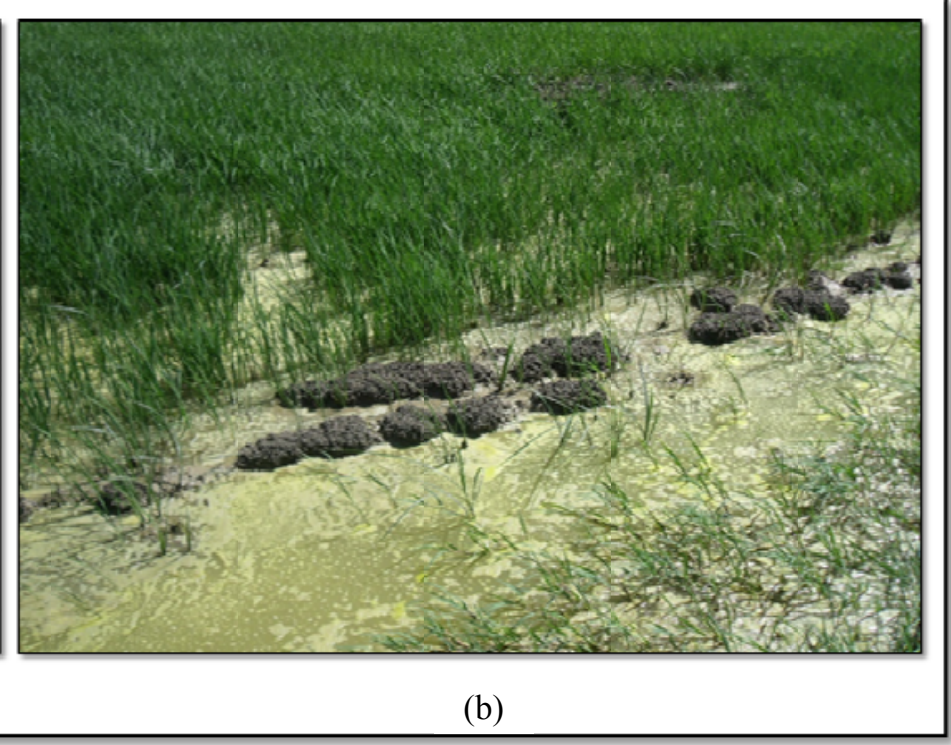

Fig. 6 Galleries inside the rice fields of Gharb area, Morocco, 2016. 


\section{Impact on Rice Growing}

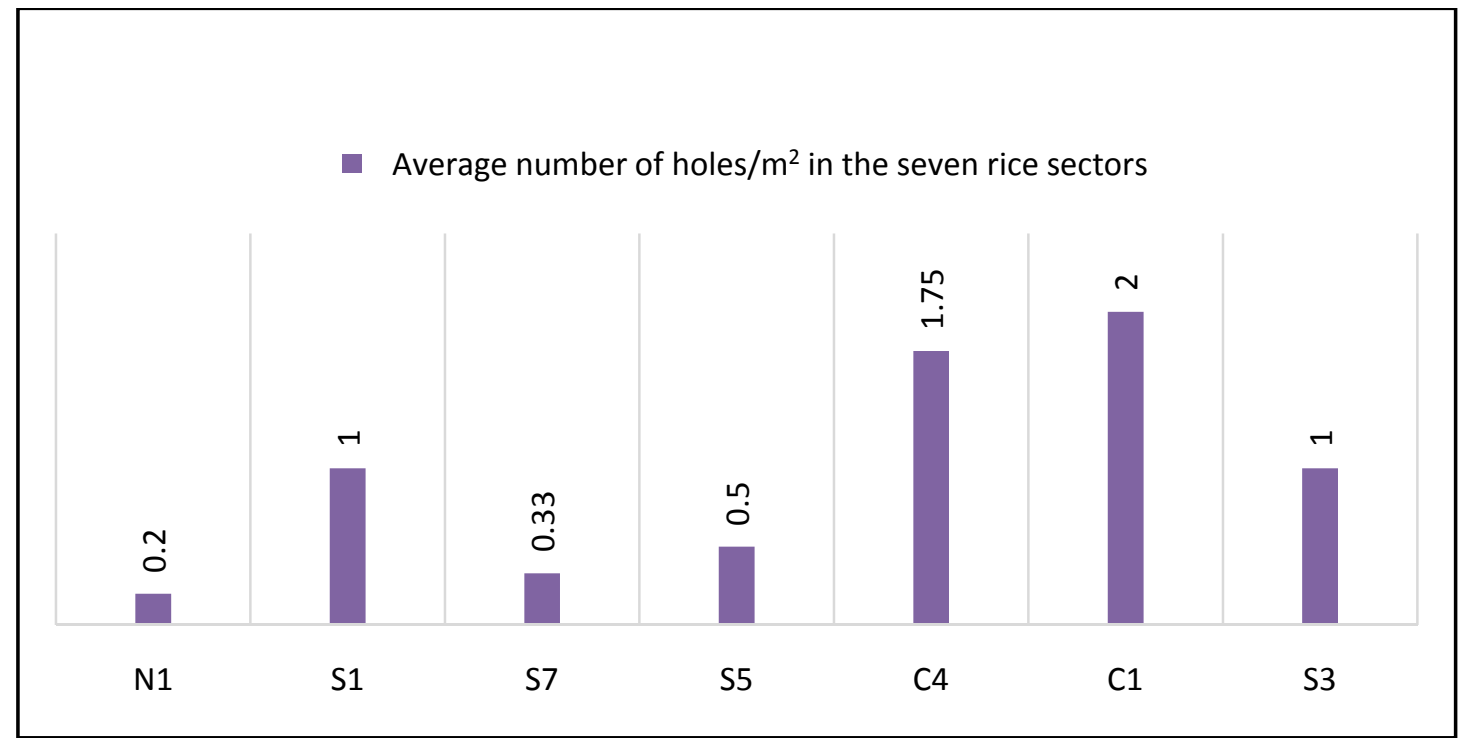

Fig. 7 Average number of holes dug by $P$. clarkii $/ \mathbf{m}^{2}$ in the rice sectors, Gharb area, Morocco, 2016.

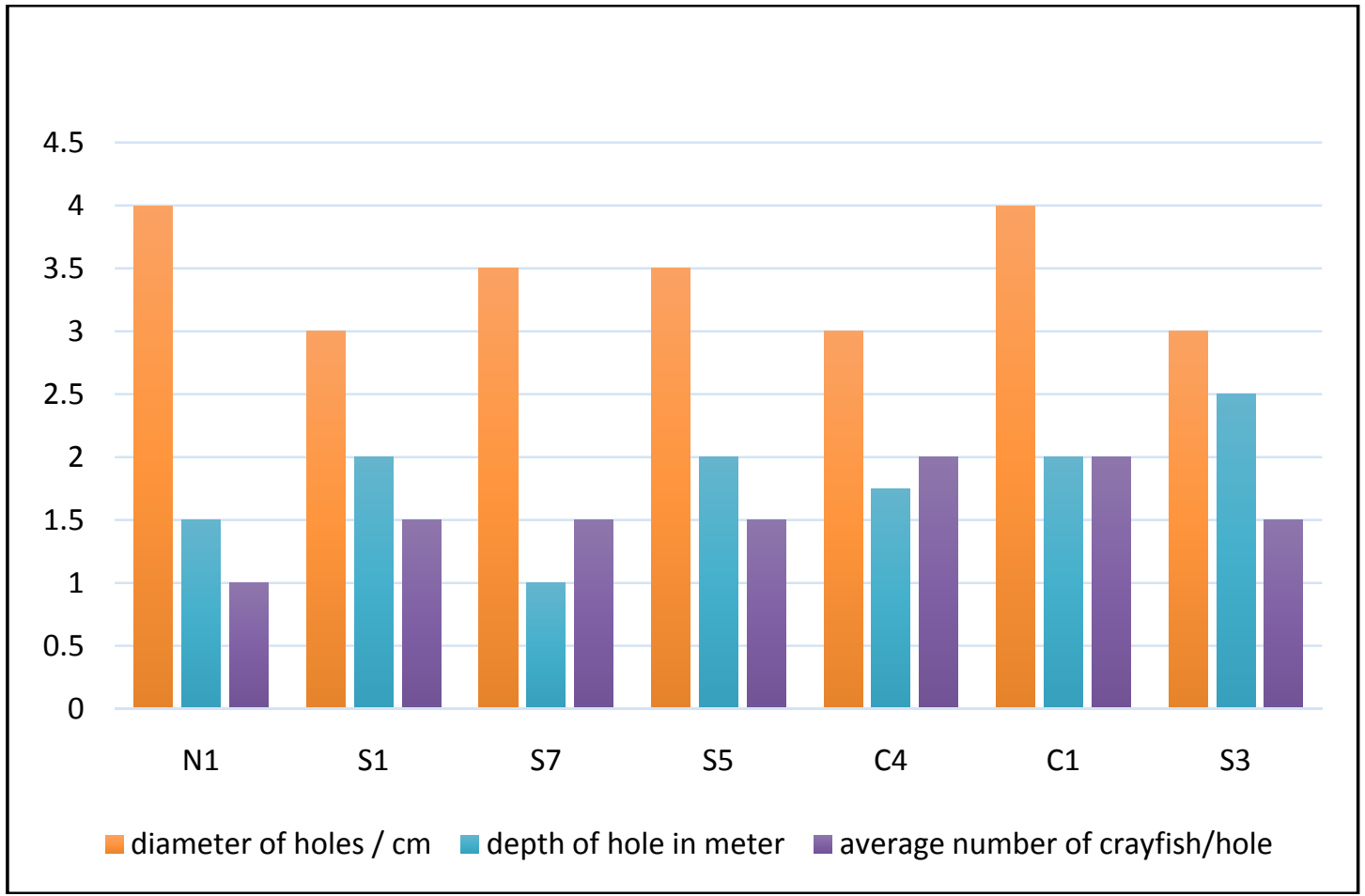

Fig. 8 Hole size and number of red swamp cryfish/hole in the rice sectors, Gharb area, Morocco, 2016.

The tunnels dug by the $P$. clarkii in the rice fields induce losses of irrigation water. These water losses can be calculated using field data and others collected from the Gharb Regional Agricultural Development Authority. This calculation method will not take into consideration the horizontal infiltration along the hole, the soil permeability rate and the water holding capacity of each soil type.

\subsubsection{Calculation of Water Loss}

A hole is supposed to be an impermeable cylinder; $R$ is a radius (medium) of hole. $R=$ diameter $/ 2=$ $3.43 / 2=1.715 \mathrm{~cm} ; P$ is a depth (average) of hole. $P=$ $182 \mathrm{~cm} ; \mathrm{Pi}=3.14$. So the volume of a hole is $V=\mathrm{Pi} \times$ $R^{2} \times P=1,680.8 \mathrm{~cm}^{3}$.

That is to say, when an irrigation operation is carried out in the rice field, each hole causes a volume 


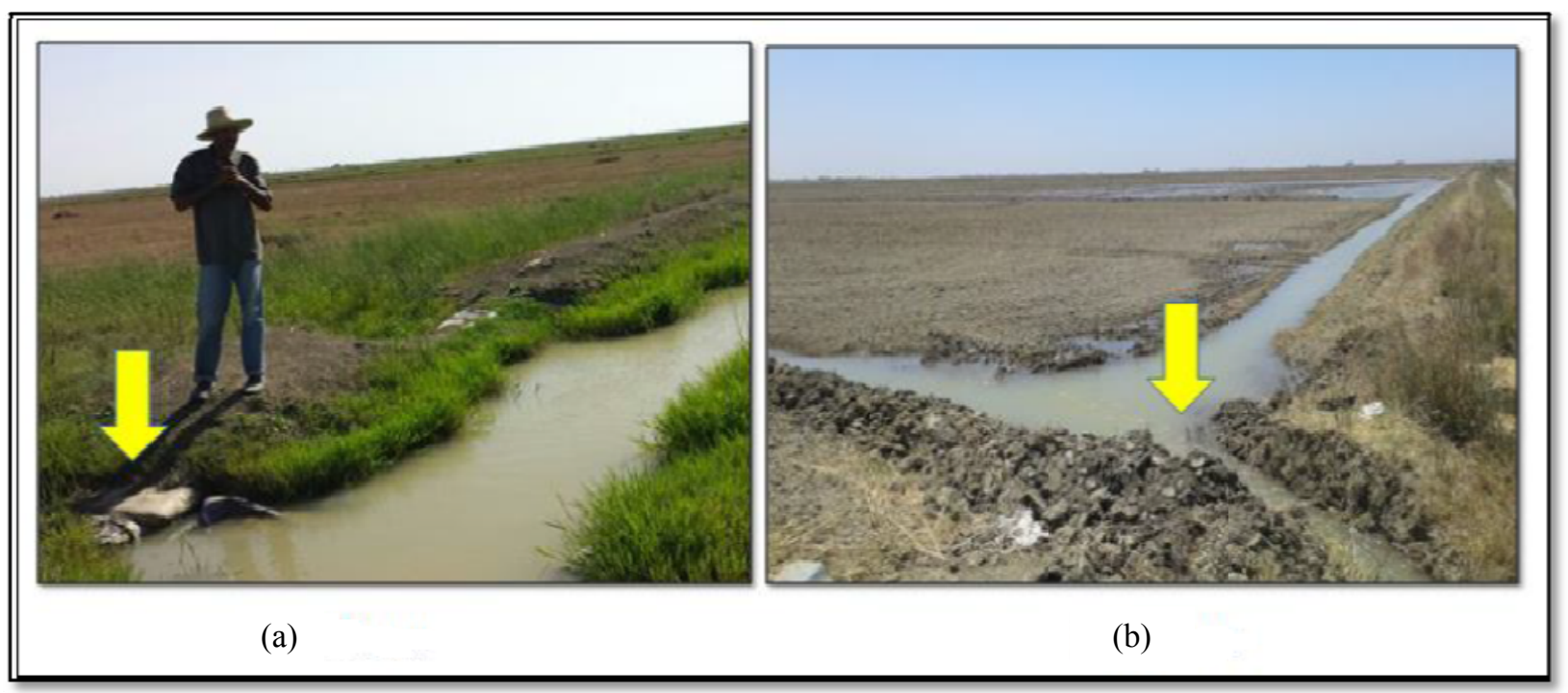

Fig. 9 Blockage (a) and water passage (b) in the bunds, Gharb area, Morocco, 2016.

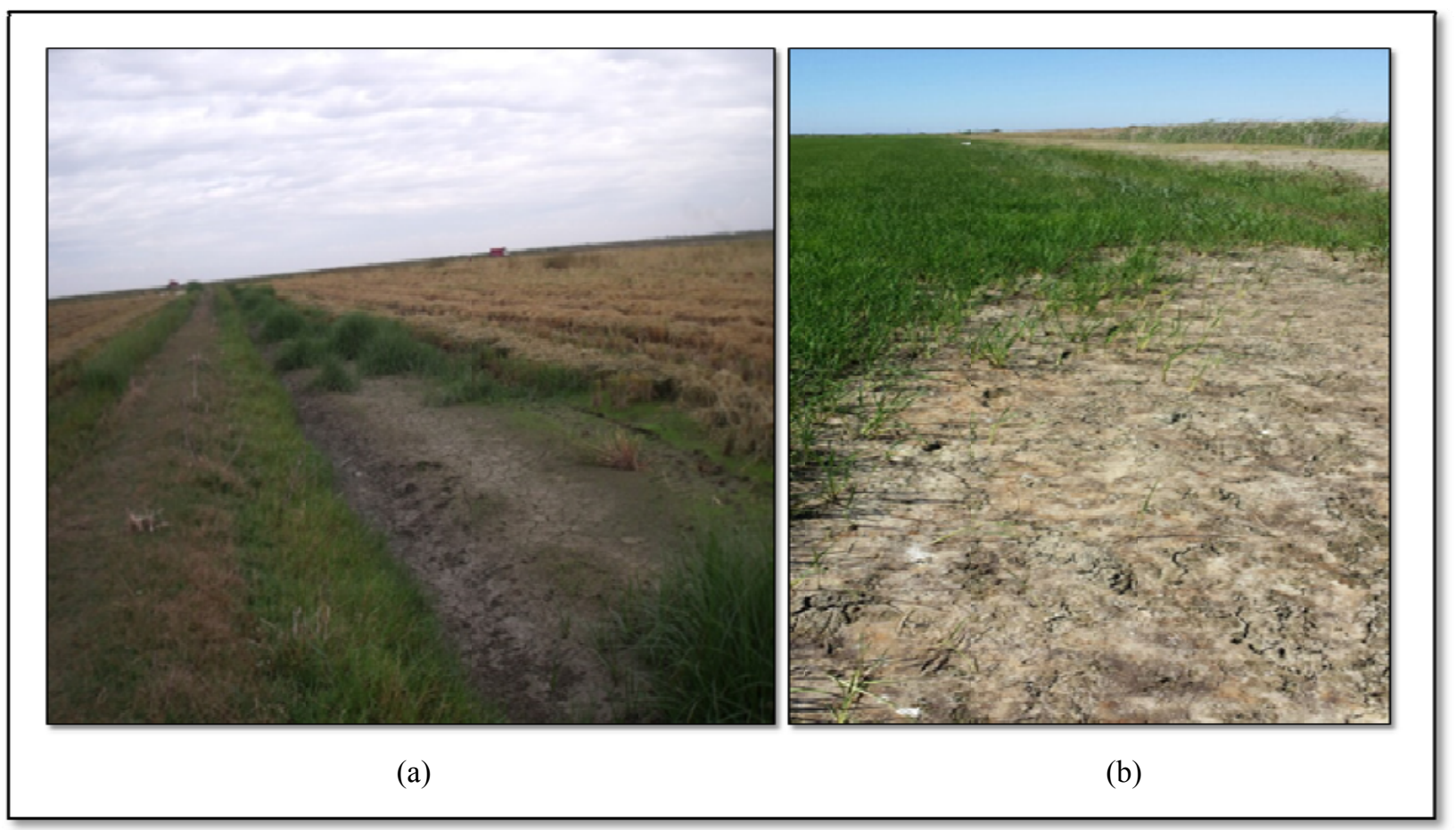

Fig. 10 Phenomenon of loss of arable land, Gharb, Morocco, 2016.

of water equivalent to $1,680.8 \mathrm{~cm}^{3}$ to be lost.

Furthermore, in an area of $1 \mathrm{~m}^{2}$, there is an average of 0.97 holes. Then in 1 ha there are 9,700 holes, because $1 \mathrm{ha}=10,000 \mathrm{~m}^{2}$. As a result, $9,700 \times 1,680.8$ $=16,303,760 \mathrm{~cm}^{3}$ which corresponds to the volume of water lost per hectare through the holes during an irrigation operation. So the water loss is $16.304 \mathrm{~m}^{3} / \mathrm{ha}$ per irrigation operation.
Moreover, in 2015, four fillings were carried out [8] for a total of $12,500 \mathrm{~m}^{3} /$ ha due to $4,500 \mathrm{DH} / \mathrm{ha}$ (ORMVAG, 2016b).

According to the previous result, it is deduced that during the year 2015, the crayfish holes lost water equivalent to $16.304 \times 4=65.216 \mathrm{~m}^{3} / \mathrm{h}$. With a rule calculation of three, this loss corresponds to a loss of $65.216 \times 4,500 / 12,500 \approx 23.478 \mathrm{MAD} / \mathrm{ha}$. 
Thus, in 2015, the red swamp crayfish caused water loss averaging $65.216 \mathrm{~m}^{3} / \mathrm{ha}$. This loss amounts to an amount equivalent to $23.478 \mathrm{MAD} / \mathrm{ha}$.

In addition, assuming that the 12,000 ha of land developed for rice cultivation are exploited, this would result in a total water loss of $65.216 \times 12,000=$ $782,592 \mathrm{~m}^{3}$, or $23.478 \times 12,000=281,736.00 \mathrm{MAD}$.

In total, the red swamp crayfish holes present in the rice fields have caused water losses that are estimated at 281,736.00 MAD during 2015 .

\subsubsection{Calculation of Yield Loss}

Red swamp crayfish attacks plants on different levels and it is during the whole period of cultivation [15]. First, the adult stage crayfish consumes seedlings, usually from the second week of planting. This is one of the periods when this species is most active in attacking the rice crop. After the plants pass this stage and develop further, the crayfish continues to cause damage, particularly with its burial activity that affects the roots of plants (rice farmers in the Gharb area, Morocco, 2016). Thus, during the entire period of rice cultivation, the crayfish continues to cause losses, causing a reduction in production and therefore in agricultural yield.

Before the appearance of $P$. clarkia, the rice yield was between 300 bags and 320 bags of rice/2.5 ha and $1 \mathrm{bag} \approx 80-90 \mathrm{~kg}$.

After the appearance of $P$. clarkii, the yield increased was between 260 bags and 280 bags of rice under the same conditions. Reduction of 40 bags of rice/ 2.5 ha, that means 16 bags/ha.

So the loss estimation is between $16 \times 80$ and $16 \times$ $90 \approx 1,280 \mathrm{~kg} / \mathrm{ha}$ and $1,440 \mathrm{~kg} / \mathrm{ha}$.

Also knowing that farmers sell the kilogram of rice at 3.3 MAD, this loss is estimated between 1,280 $\times 3.3$ and $1,440 \times 3.3 \approx 4,224.00 \mathrm{MAD} / \mathrm{ha}$ and $4,752.00$ $\mathrm{MAD} / \mathrm{ha}$.

Similarly, assuming that the 12,000 ha of irrigated rice area are exploited, rice losses would be between $4,224 \times 12,000$ and $4,752 \times 12,000 \approx 50,688,000.00$ MAD and 57,024,000.00 MAD in 2015.

\subsubsection{Loss of Cultivable Area}

The red swamp crayfish arrives in the rice fields following the water that enters the bunds at the time of filling. It digs horizontally (unlike the usual vertical digging that allows it to make the galleries) to enter the rice fields, thus opening water passages. This phenomenon acts directly on the cultivable surfaces that are close to these water passages. Indeed these passages cause small floods that affect the surfaces near the source of water and make them later unusable to rice cultivation. The more abundant the crayfish are, the more important their digging activities become and therefore the plots of land become unusable (Figs. 10a and 10b).

\section{Conclusions}

The first sightings of the Louisiana crayfish in the Gharb area date from 2008. With a great capacity for adaptation, the population of this species has steadily increased with significant proportions. Currently (eight years ago), there are 15,220 crayfish per hectare in the rice fields.

Wanting to exploit the Louisiana crayfish by breeding in the Gharb area does not seem to be an option since it means accepting the negative impacts that will result. The Gharb area contains one of the most important agricultural potential in Morocco. It produces most of the Moroccan rice.

The presence of the red swamp crayfish in the Gharb area represents a real ecological threat through the disruption of inland water biodiversity and in agriculture. In the rice fields, in particular, there is a sizeable population that causes damage.

The estimated water losses are $65,215 \mathrm{~m}^{3} / \mathrm{ha}$ of irrigation during this study amount to $23,480 \mathrm{MAD} / \mathrm{ha}$ or $€ 2.16 /$ ha because $1 \mathrm{MAD}=€ 0.0919219$ (estimate at $31 / 08 / 2016$ ).

Rice losses, reported by rice growers, would be between 4,224 MAD/ha and 4,752 MAD/ha, or between $€ 388.28 / \mathrm{ha}$ and $€ 436.52 / \mathrm{ha}$.

Non-exploitation losses for recovery of the crayfish 
product, that is to say, the amount of crayfish present in the fields and that could be exploited but which is not, vary between 1,505.00 $\mathrm{MAD} / \mathrm{ha}$ and 3,010 MAD/ha (i.e., $€ 138.34 /$ ha and $€ 276.68 /$ ha).

A fight against this species must be initiated and requires the intervention of several ecological actors, institutions, researchers and local populations. This control campaign must above all go through an awareness that affects the local populations, likewise and given its nutritional and economic value.

It is time to sound the alarm because without immediate intervention, this species will do the great damage in the Gharb area and then repair all over Morocco. That's why you need strong awareness among farmers and local populations, a census of invasive fauna species to create a database, prohibit the importation, transport and marketing of P. clarkii to the living state, and encourage intensive fishing for this species.

\section{Acknowledgments}

This work was made possible thanks to the rice growers of the Gharb areas (northwest of Morocco) for their help, also thank the regional office of the agricultural development of Gharb for their useful documents, thanks also go to Mr. Lhbib Jdi, chief engineer at DREFLCD North West Kenitra Morocco for his helpful comments.

\section{References}

[1] Sala, O. E., Chapin III, F. S., Armesto, J. J., Berlow, E., Bloomfield, J., Dirzo, R., Huber-Sannwald, E., Huenneke, L., Jackson, R. B., Kinzig, A., Leemans, R., Lodge, D. M., Mooney, H. A., Oesterheld, M., Poff, N. L., Sykes, M. T., Walker, B. H., Walker, M., and Wall, D. H. 2000. "Biodiversity Scenarios for the Year 2100." Science 287: 1770-4.

[2] Ewel, J. J., O’Dowd, D. J., Bergelson, J., Daehler, C. C., D’Antonio, C. M., Gomez, D., Gordon, D. R., Hobbs, R. J., Holt, A., Hopper, K. R., Hughes, C. E., Lahart, M., Leakey, R. R. B., Lee, W. G., Loope, L. L., Lorence, D. H., Louda, S. M., Lugo, A. E., Mcevoy, P. B., Richardson, D. M., and Vitousek, P. M. 1999. "Deliberate Introductions of Species: Research Needs: Benefits Can
Be Reaped, but Risks Are High.” BioScience 49 (8): 619-30.

[3] Williamson, M., and Fitter, A. 1996. "The Varying Success of Invaders.” Ecology 77: 1666-70.

[4] Jerscke, J. M., and Strayer, D. L. 2005. "Invasion Success of Vertebrates in Europe and North America." Proc. Nat. Acad. Sci. USA 102: 7198-202.

[5] Kolar, C. S., and Lodge, D. M. 2001. "Progress in Invasion Biology: Predicting Invaders." Trends Ecol. Evol. 16: 199-204.

[6] Collas, M., Chambry, F., Loeffel, W., and Lafon, S. 2008 "Red Swamp Crayfish (Procambarus clarkii) First Observation in Lorraine." National Office of Water and Aquatic Environments, 20.

[7] Girard, 1852. "Population Biology and Production of the Red Swamp Crayfish Procambarus clarkii (Girard) in the Lower Mondego River Valley, Portugal.” Journ. Crustacean Biol. 15 (1): 156-68.

[8] Sandrin, E. 1991. "Contribution to the Study of Procambarus clarkii Louisiana Crayfish." Ph.D. thesis Med. Vet., Toulouse, France, 90.

[9] Souty-Grosset, C., Holdich, D., Noel, P., Reynolds, J., and Haffner, P. 2006. Atlas of Crayfish in Europe. Publications Scientifiques NHN (Museum National d'Histoire Naturelle Patrimoines Naturels), Paris 64, 187.

[10] Kugler, E. 2013. "Biological Invasion Processes in Metropolitan France: Examples of American Mink (Neovison vison), Florida Turtle (Trachemys scripta elegans) and Louisiana Crayfish (Procambarus clarkii)." Ph.D. thesis Med. Vet. Creteil, 167.

[11] Lerat, D., Paris, L., and Baran, P. 2006. "Status of the White-Clawed Crayfish (Austropotamobius pallipes Lereboullet, 1858) in Burgundy: Assessment of 5 Years of Prospection.” Bull. Fishing Piscic. 380-381: 867-82.

[12] Laurent, P. J. 1997. "Crayfish Introductions into France and in the World, History and Consequences." Bull. Fr. Pêche Piscic. 344-345: 345-56.

[13] EL Qoraychy, I. 2016. "Biological and Ecotoxicological Study of the Louisiana Crayfish (Procambarus clarkii) after Its Introduction in the Plain of Gharb, Morocco." Ph.D. thesis, Mohamed 5 University, Faculty of Sciences Rabat.

[14] Regional Office for Agricultural Development of Gharb, Kenitra, Morocco. 2016. Effect of Technical and Commercial Constraints on the Development of Rice Cultivation in Gharb, 5-32.

[15] Morolli, C., Quaglio, F., Della Rocca, G., Malvisi, J., and Di Salvo, A. 2006. "The Result of This Study Is That of Crayfish (Procambarus clarkii, Girard 1852) and Common Carp (Cyprinus carpio L. 1758).” Bull. Fishing Piscic. 380-381: 1381-94. 